Article

\title{
Grain Handling and Storage in Lubero and Rutshuru Territories in the North Kivu Province, the Democratic Republic of Congo
}

\author{
Dieudonne Baributsa $\left.{ }^{1, *} \mathbb{(}\right)$, Jorge R. Díaz-Valderrama ${ }^{1}\left(\mathbb{D}\right.$, Déogratias Mughanda $^{2}$, André Lubanzadio $^{3}$, \\ Jean Paul C. Nshombo ${ }^{4}$, Louise Sperling ${ }^{5}\left(\mathbb{D}\right.$ and Ibrahim B. Baoua ${ }^{6}$ \\ 1 Department of Entomology, Purdue University, 901 W. State Street, W. Lafayette, IN 47907, USA; \\ jronny.diaz@gmail.com \\ 2 Catholic Relief Services, Goma, North Kivu, Democratic Republic of the Congo; jide.mughanda@gmail.com \\ 3 Fédération des Organisations des Producteurs Agricoles du Congo, BP 647, \\ Goma, Nord Kivu, Democratic Republic of the Congo; lubanzadiolubain@gmail.com \\ 4 Land O'Lakes, Kinshasa, Democratic Republic of the Congo; jeanpaulnshombo654@gmail.com \\ 5 SeedSystem, Sherman, CT 06784, USA; sperling@seedsystem.org \\ 6 Département des Sciences et Techniques de Productions Végétales, Université Dan Dicko Dankoulodo de \\ Maradi, Maradi BP 465, Niger; baoua.ibrahim@gmail.com \\ * Correspondence: dbaribut@purdue.edu; Tel.: +1-765-494-8713
}

\section{check for}

updates

Citation: Baributsa, D.;

Díaz-Valderrama, J.R.; Mughanda, D.;

Lubanzadio, A.; Nshombo, J.P.C.;

Sperling, L.; Baoua, I.B. Grain

Handling and Storage in Lubero and

Rutshuru Territories in the North

Kivu Province, the Democratic

Republic of Congo. Sustainability

2021, 13, 9580. https://doi.org/

$10.3390 /$ su13179580

Academic Editor: Michael S. Carolan

Received: 17 July 2021

Accepted: 23 August 2021

Published: 25 August 2021

Publisher's Note: MDPI stays neutral with regard to jurisdictional claims in published maps and institutional affiliations.

Copyright: (c) 2021 by the authors. Licensee MDPI, Basel, Switzerland. This article is an open access article distributed under the terms and conditions of the Creative Commons Attribution (CC BY) license (https:/ / creativecommons.org/licenses/by/ $4.0 /)$.

\begin{abstract}
Postharvest management of grain and seed is a challenge among smallholder farmers. Limited information is available on how smallholder farmers in eastern Democratic Republic of Congo (DRC), who have been exposed to multiple conflicts, manage grain and seed after harvest. We interviewed 690 smallholder farmers in Lubero (Baswagha chiefdom) and Rutshuru (Bwisha and Bwito chiefdoms) territories of the North Kivu province of the DRC to assess how they dried and stored their crops. Results reveal that $95 \%$ and $80 \%$ farmers produced beans and maize, respectively. About half of respondents in Bwisha grew soybean, suggesting production diversification using conflict-resistant crops to minimize thefts and looting. Rotting and theft were the major challenges during field drying, while insects $(81.3 \%$ ) were the most important issue during storage. Sixty-six percent of farmers did not protect their grain during storage, exposing it to insect damage. Farmers producing beans in both Bwisha and Bwito, farmers storing beans and maize, and those storing for more than three months were more likely to protect their grains during storage. More than $70 \%$ of farmers saved seed for planting the next season but suffered significant weight losses of up to $50 \%$ due to insects. Storing grain in hermetic bags for six months had an estimated return on investments of up to $63 \%$ for maize in Baswagha and $54 \%$ for beans in Bwisha. Improved drying and storage technologies would help smallholder farmers to reduce their grain postharvest losses due to mold, theft, and insects. Smallholder farmers using these improved postharvest technologies have the opportunity to secure quality grain for home consumption and sale, and seed for planting.
\end{abstract}

Keywords: postharvest management; maize; common beans; storage loss; hermetic technologies

\section{Introduction}

Postharvest management of grain and seed is a major challenge in the Democratic Republic of Congo (DRC). North Kivu, one of the 27 provinces in the DRC, is located in the eastern area and shares its borders with Uganda and Rwanda. North Kivu has great agricultural potential due to its diverse topography, climate, and dynamic population [1]. For decades, the province had been considered the breadbasket of the whole country, supplying food to national and international markets [2,3]. However, the province's prominence in agriculture started to decline in the mid-1990's, due to a rise in armed conflicts that created instability and massive displacement of rural populations [4-6]. The insecurity caused by internal conflicts has deterred farmers from investing in agricultural production [5]. 
Agriculture plays a significant role in North Kivu, contributing to about $57 \%$ of the province's economy [7]. In fact, amongst all provinces in the DRC, North Kivu has the second largest number of agricultural households (HHs), estimated at 1.23 million, following South Kivu with 1.35 million [8]. The province produces cereal and legumes, vegetables, fruits, tubers, tea, coffee, and cattle [9]. Further, North Kivu is the major producer of common beans (Phaseolus vulgaris L.) in the DRC, supplying about $89 \%$ of the country' stock during the 2009-2014 period [10]. The beans produced in North Kivu are commercialized mainly in South Kivu, Kinshasa, Kisangani, and Kasai, and are even exported to Rwanda, Uganda, and Burundi [11]. About 32,000 tons of beans produced in North and South Kivu were traded seasonally between DRC, Rwanda, Burundi, and Uganda in early 2000's [11].

Grain and seed storage have been major challenges in the DRC. Assessments conducted in the DRC found that farmers lose substantial quantities (25 to 95\%) of maize and legumes during storage [12,13]. These losses are mainly due to poor postharvest management and limited access to insecticides [13]. Sources of postharvest losses include insects, poor storage conditions, rodents, diseases, theft, and livestock [14]. Recent studies implemented in both the North and South Kivu provinces revealed that poor handling and storage have also contributed to low crop production (e.g., common beans) [10]. Further, improved storage technologies to preserve cereals and legumes have not been widely disseminated and remain largely unavailable [15]. Seed storage has been a major production constraint in North Kivu. Challenges during seed drying and storage lead to low-quality planting materials that reduce crop yields. In the absence of good and reliable seed systems, smallholder farmers in North Kivu mainly buy seed of varying quality from local markets, and save and reuse it in following years [9]. In such circumstances, helping farmers to preserve the quality of their own or local sources of seed becomes critical.

Complementary studies assessed the efficacy of natural products to control stored product insect pests on beans and maize (Zea mays L.) in eastern DRC $[16,17]$. Results revealed that some plant extracts and powders (e.g., Eucalyptus citriodora, Cupressus lusitanica, Citrus limon, etc.) are effective at controlling insects such as Sitophilus spp. and Acanthoscelides obtectus. Despite these interesting results, there is no evidence that farmers have adopted these technologies. In fact, surveys conducted by various projects showed that less than $10 \%$ of farmers used improved storage methods [15]. We conducted this survey to assess postharvest management of grain/seed by smallholder farmers in Lubero and Rutshuru territories in North Kivu. The objectives were to: (i) understand the major cereal and legume grains produced by smallholder farmers; (ii) document how farmers handled grain (drying) right before and after harvest; (iii) gain insights into grain and seed storage practices, sources of losses, and protection methods; and (iv) estimate the profitability of grain storage.

\section{Materials and Methods}

\subsection{Survey Area and Context}

This study was conducted in 2016 in Lubero (Baswagha chiefdom) and Rutshuru (Bwisha and Bwito chiefdoms) territories of the North Kivu province in eastern DRC. Respondents were selected among smallholder farmers in the project areas (Figure 1). Figure 1 was obtained by mapping with $\mathrm{R}$ package mapview [18] and the coordinates collected during the survey using the GPS locator feature embedded in the KoboCollect Application. Then, these locations were appended into the Scalable Vector Graphics (".svg") format maps of the DRC and North Kivu, shared by Afrogindahood under Creative Commons Attribution-Share Alike 4.0 International license in Wikimedia Commons (https:/ / commons.wikimedia.org/, accessed on 25 November 2020). 
Democratic Republic of Congo

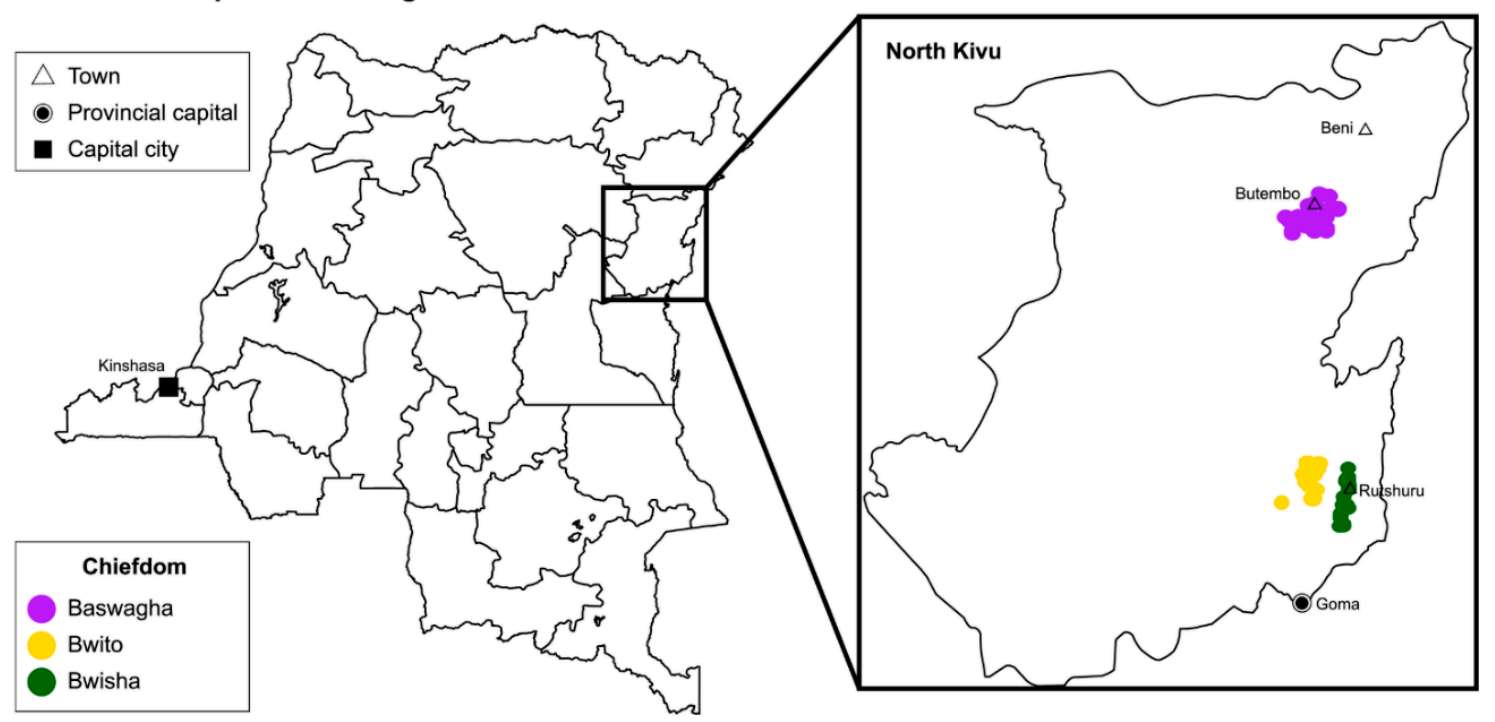

Figure 1. Map showing approximate survey locations in the three chiefdoms where the study was implemented in the North Kivu province, D. R. Congo.

The province of North Kivu, a mountainous region with savannas and plateaus crossed by the Equator, has several soil types that are generally fertile, including volcanic soils. Two major types of climate determine the variations in temperature and rainfall: the tropical Afro-mountain climate in the highlands and the Guinean-equatorial climate in the lowlands [1]. The climate is temperate but there is a correlation between temperature and elevation. Average temperatures range from $15{ }^{\circ} \mathrm{C}$ at $2000 \mathrm{~m}$ above seas level (a.s.1.) to about $23{ }^{\circ} \mathrm{C}$ below $1000 \mathrm{~m}$ a.s.1. [1]. The study was conducted south of the Equator where average annual rainfall varies between $1000 \mathrm{~mm}$ to $2000 \mathrm{~mm}$, with two rainy seasons: September-December (major) and February-June (minor).

\subsection{Sampling and Data Collection}

This study was part of a postharvest project funded and implemented by the nongovernmental organization (NGO) Catholic Relief Services (CRS). The project was implemented in only 544 villages in three chiefdoms in the North Kivu province (218 villages in Baswagha, 190 villages in Bwisha, and 136 villages in Bwito), given the prevailing insecurity and limited accessibility. We randomly selected 91 villages (36 in Baswagha, 32 in Bwisha, and 23 in Bwito) for this survey, based on the proportion of the 544 villages assigned to each of the three chiefdoms. In each village, we randomly selected eight farmers out of a list of 15 HHs established by the extension agent in collaboration with the head of the village. The $15 \mathrm{HHs}$ were not randomly selected due to security concerns of enumerators and respondents. The names of farmers from the $15 \mathrm{HHs}$ were placed in a small basket once they arrived at the meeting, and the first eight farmers selected were interviewed. We originally aimed to interview 728 farmers but reached 690 respondents (about a 95\% response rate). Insecurity in some villages led to a low turnout.

Android tablets with a questionnaire uploaded in KoboCollect application [19] were used to administer the survey. The survey had open- and close-ended questions. Data collected included: (i) socio-demographic information; (ii) access to information; (iii) crops produced and quantity; (iv) field drying techniques and challenges; (v) storage practices, quantity stored and challenges, and quantity consumed; (vi) stored grain protection methods; (vii) prices of grains at harvest and during lean season; and (viii) seed storage, quantity stored, and challenges. Questions on the challenges and source of loss during field drying and storage were non-ranked multiple option questions. 


\subsection{Data Analysis}

Data were downloaded from KoboCollect, cleaned, and formatted to be analyzed in an R package survey [20]. In the analysis, each interviewee was weighted based on finite-population correction (FPC) values obtained from the estimated number of $\mathrm{HHs}$ in each chiefdom. These values were calculated using the number of villages in the North Kivu chiefdoms and population estimates previously reported [21,22]. To differentiate farmers' characteristics in terms of production, grain storage, and seed storage in the three chiefdoms under this study, we performed a Kruskal-Wallis test using an R package agricolae [23]. The factors affecting decisions to store and protect grain or seed under storage were assessed using logistic regression analyses. These analyses aimed at finding statistical significance of variables which increased or decreased the probability to store and protect grain or seed. The logistic regression models were tested for fitness using the likelihood ratio (LR) test. Finally, we analyzed the potential return on investment (ROI) of storing grain using hermetic bags for a six-month period by comparing grain prices at harvest and during the lean season. Grain price information was provided by interviewees and we used the retail price of a 100-kg Purdue Improved Crop Storage (PICS) hermetic bag in North Kivu. Descriptive statistics, logistic regression, and ROI analyses were performed following the methods applied in previous survey-based agricultural studies [24,25]. All variables resulting from the survey were categorical, except for "household size", grain "quantities" (produced, stored, and consumed), and the quantity of seed stored. Quantity produced and stored were transformed (natural logarithm) only in the logistic regression analyses. The significance threshold in all analyses was $p<0.05$.

\section{Results}

\subsection{Demographics}

There were similarities and differences in the demographic characteristics of farmers in the three chiefdoms in North Kivu (Table 1). The majority of respondents were female $(60.2 \%)$, had a primary or high school education $(68.5 \%)$, and were married $(82.2 \%)$

Table 1. Demographic characteristics of farmers in Baswagha, Bwisha, and Bwito chiefdoms of the North Kivu province, D. R. Congo.

\begin{tabular}{|c|c|c|c|c|c|}
\hline & & Baswagha & Bwisha & Bwito & Total \\
\hline & & \multicolumn{4}{|c|}{ Percentage (Standard Error) } \\
\hline Variable & Category & $n=271$ & $n=236$ & $\mathrm{n}=183$ & $n=690$ \\
\hline \multirow{2}{*}{ Gender (\%) } & Female & $62.4(2.9)$ & $58.9(3.2)$ & $56.3(3.6)$ & $60.2(1.9)$ \\
\hline & Male & $37.6(2.9)$ & $41.1(3.2)$ & $43.7(3.6)$ & $39.8(1.9)$ \\
\hline \multirow{4}{*}{ Marital Status (\%) } & Married & $79.7(2.4)$ & $81.4(2.5)$ & $92.9(1.9)$ & $82.2(1.5)$ \\
\hline & Single & $17(2.3)$ & $5.1(1.4)$ & $0.5(0.5)$ & $10.3(1.2)$ \\
\hline & Widow & $2.2(0.9)$ & $11.9(2.1)$ & $6.6(1.8)$ & $6.3(0.9)$ \\
\hline & Divorced & $1.1(0.6)$ & $1.7(0.8)$ & $0.0(0.0)$ & $1.2(0.4)$ \\
\hline \multirow{4}{*}{ Age (\%) } & 20-30 years & $23.6(2.6)$ & $19.1(2.5)$ & $26.8(3.2)$ & $22.4(1.6)$ \\
\hline & $31-40$ years & $27.3(2.7)$ & $28.4(2.9)$ & $23(3.1)$ & $27.1(1.8)$ \\
\hline & $41-50$ years & $22.1(2.5)$ & $24.2(2.8)$ & $27.3(3.2)$ & $23.6(1.7)$ \\
\hline & 50 years and more & $26.9(2.7)$ & $28.4(2.9)$ & $23(3.1)$ & $26.9(1.8)$ \\
\hline \multirow{5}{*}{ Education level (\%) } & No education & $18.8(2.4)$ & $32.2(3.0)$ & $38.8(3.5)$ & $26.6(1.7)$ \\
\hline & Literacy & $2.2(0.9)$ & $2.1(0.9)$ & $5.5(1.7)$ & $2.7(0.6)$ \\
\hline & Primary & $47.6(3.0)$ & $38.1(3.2)$ & $38.8(3.5)$ & $42.9(1.9)$ \\
\hline & High School & $28.4(2.7)$ & $25.8(2.8)$ & $16.9(2.7)$ & $25.8(1.7)$ \\
\hline & Superior & $3.0(1.0)$ & $1.7(0.8)$ & $0.0(0.0)$ & $2.1(0.6)$ \\
\hline \multirow{4}{*}{ Main Activity (\%) } & Agriculture & $87.1(2.0)$ & $91.5(1.8)$ & $97.3(1.2)$ & $90.2(1.2)$ \\
\hline & Full time job & $11.1(1.9)$ & $5.1(1.4)$ & $1.6(0.9)$ & $7.5(1.0)$ \\
\hline & Trade & $1.1(0.6)$ & $3.0(1.1)$ & $0.5(0.5)$ & $1.7(0.5)$ \\
\hline & Other & $0.7(0.5)$ & $0.4(0.4)$ & $0.5(0.5)$ & $0.6(0.3)$ \\
\hline
\end{tabular}


There were more respondent widows in Bwisha than in Baswagha and Bwito. The respondents' $\mathrm{HH}$ average size was seven people. The main economic activity of the respondents was agriculture $(90.2 \%)$. The majority of farmers in Baswagha and Bwito had contact with extension services (NGOs, projects, international agencies, etc.). Out of all the farmers who had contact with extension agents, $56.1 \%$ were female and $43.9 \%$ were male.

\subsection{Cereal and Legume Crops Grown, and Postharvest Grain Handling}

The most important cereal and legume crops produced by farmers in the three chiefdoms were beans $(95.3 \%)$ and maize (80.4\%) (Table 2). Minor grain crops of importance included soybean (Glycine max), sorghum (Sorghum bicolor), and peanut (Arachis hypogaea). Soybean was the most cultivated minor crop, planted by $47.5 \%$ of farmers in Bwisha (Table 2).

Table 2. Main cereal and legume crops produced, sources of losses during field drying, and drying methods in Baswagha, Bwisha, and Bwito chiefdoms of the North Kivu province, D. R. Congo.

\begin{tabular}{|c|c|c|c|c|}
\hline & Baswagha & Bwisha & Bwito & Total \\
\hline Variables/Categories & \multicolumn{4}{|c|}{ Percentage (Standard Error) } \\
\hline Farmers producing cereal/legume crops $(\%)^{a}$ & $\mathrm{n}=271$ & $\mathrm{n}=236$ & $\mathrm{n}=183$ & $\mathrm{n}=690$ \\
\hline Beans & $92.6(1.6)$ & $97.9(0.9)$ & $97.8(1.1)$ & $95.3(0.9)$ \\
\hline Maize & $70.8(2.8)$ & $91.1(1.8)$ & $86.3(2.5)$ & $80.4(1.6)$ \\
\hline Soybean & $10.0(1.8)$ & $47.5(3.2)$ & $2.2(1.1)$ & $22.3(1.5)$ \\
\hline Sorghum & $0.0(0.0)$ & $17.4(2.5)$ & $20.2(2.9)$ & $9.2(1.0)$ \\
\hline Peanut & $2.2(0.9)$ & $11.4(2.1)$ & $18.6(2.8)$ & $7.9(1.0)$ \\
\hline Millet & $0.0(0.0)$ & $0.8(0.6)$ & $2.7(1.2)$ & $0.7(0.3)$ \\
\hline Rice & $0.7(0.5)$ & $0.0(0.0)$ & $0.5(0.5)$ & $0.4(0.3)$ \\
\hline Source of losses during field drying $(\%)^{a}$ & $\mathrm{n}=252$ & $\mathrm{n}=153$ & $\mathrm{n}=177$ & $\mathrm{n}=582$ \\
\hline Rotting & $73.4(2.8)$ & $46.4(4.0)$ & $51.4(3.7)$ & $59.8(0.0)$ \\
\hline Animals & $43.3(3.1)$ & $47.1(4.0)$ & $33.3(3.5)$ & $42.6(0.0)$ \\
\hline Insects & $57.9(3.1)$ & $17.0(3.0)$ & $26.0(3.2)$ & $41.1(0.0)$ \\
\hline Theft & $22.2(2.6)$ & $50.3(4.0)$ & $59.9(3.6)$ & $36.5(0.0)$ \\
\hline Weather & $2.8(1.0)$ & $12.4(2.7)$ & $21.5(3.0)$ & $8.6(0.0)$ \\
\hline Fall to the ground & $2.0(0.9)$ & $1.3(0.9)$ & $0.6(0.6)$ & $1.6(0.0)$ \\
\hline Other & $1.6(0.8)$ & $6.5(2.0)$ & $0.0(0.0)$ & $2.7(0.0)$ \\
\hline Drying method (\%) & $\mathrm{n}=271$ & $\mathrm{n}=236$ & $\mathrm{n}=183$ & $\mathrm{n}=690$ \\
\hline Tarpaulin & $65.7(2.9)$ & $72.9(2.9)$ & $65.0(3.5)$ & $68.2(1.8)$ \\
\hline On the ground & $22.9(2.6)$ & $12.7(2.2)$ & $9.8(2.2)$ & $17.3(1.5)$ \\
\hline Mats & $1.1(0.6)$ & $13.1(2.2)$ & $24.0(3.1)$ & $8.8(1.0)$ \\
\hline Plastic sheets & $5.9(1.4)$ & $1.3(0.7)$ & $0.0(0.0)$ & $3.4(0.8)$ \\
\hline Others & $4.4(1.2)$ & $0.0(0.0)$ & $1.1(0.8)$ & $2.3(0.6)$ \\
\hline
\end{tabular}

${ }^{a}$ Multiple choice questions; respondents may have picked more than one response.

Challenges of crop handling during field drying and threshing/shelling included rotting, animal damage (e.g., livestock), insect infestation, and theft (Table 2). During field drying, both crop rotting and insect infestation were more pronounced in Baswagha ( $73.4 \%$ and $57.9 \%$, respectively) compared to the other chiefdoms. Theft was more prevalent in both Bwito (59.9\%) and Bwisha (50.3\%) than in Baswagha (Table 2). All farmers (99.9\%) relied on the sun to dry their grains. After crops were moved out of the fields, the majority of farmers $(80.3 \%)$ used tarpaulins, mats, or plastic sheets to dry their grains (Table 2). All farmers (99.9\%) shelled or threshed their crops by hand; only one farmer in Bwisha used a mechanical sheller (Table 2).

The quantity of grain produced varied by crop and chiefdom (Figure 2). Overall, farmers produced larger quantities of maize than common beans. The quantities of maize and beans produced by farmers in Baswagha (median of $50 \mathrm{~kg}$ for both crops) were significantly lower than those in Bwisha and Bwito. The quantities of maize produced in both Bwisha and Bwito were not significantly different, with a median of $240 \mathrm{~kg}$ and $220 \mathrm{~kg}$, 
respectively. However, the quantity of beans produced by a farmer in Bwisha (median of $150 \mathrm{~kg}$ ) was significantly higher than that of Bwito (100 kg) (Figure 2).
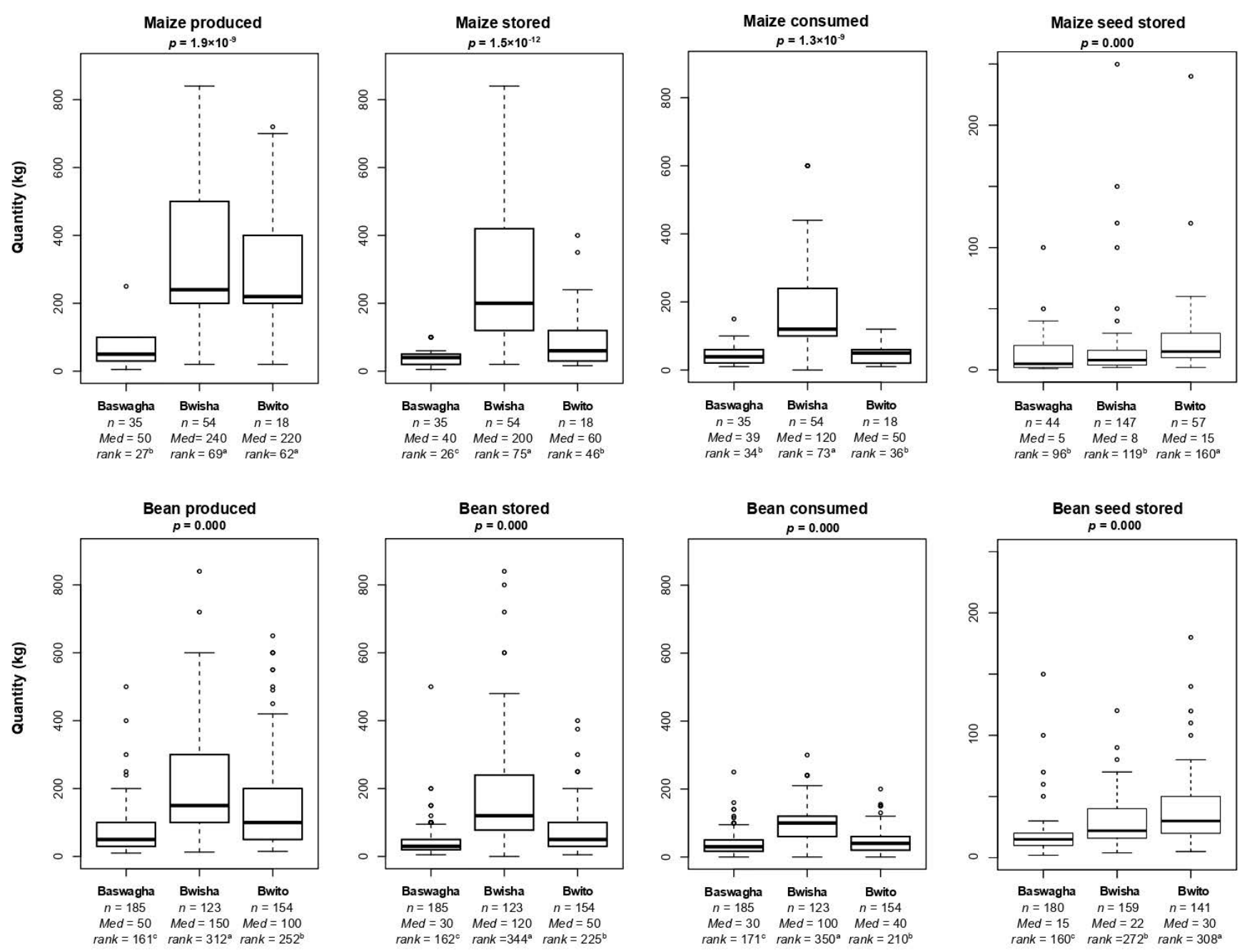

Figure 2. Grain produced and stored, and seed stored by farmers in Baswagha, Bwisha, and Bwito chiefdoms of the North Kivu province, D.R. Congo. Chiefdom boxplots with same letters on the rank are not significantly different $(p<0.001)$ based on the Kruskal-Wallis test; $\mathrm{n}$ is the number of respondents; Med is the median value in each chiefdom; and rank is the rank calculated in the Kruskal-Wallis test. Few outliers not shown, mainly in Bwisha.

\subsection{Grain Storage and Challenges}

Across the three chiefdoms, the majority of farmers (80.8\%) stored grain. Among the $19.2 \%$ of respondents who did not store grain, $47.6 \%$ said the main reason was low production (Table 3). Beans were stored by the majority ( $80.1 \%$ ) of farmers (Table 3 ). The quantity of grain stored varied among chiefdoms (Table 3 ).

Farmers in Bwisha stored significantly $(p<0.05)$ more maize (median $200 \mathrm{~kg}$ ) and beans (median $120 \mathrm{~kg}$ ) than those in Baswagha (median $40 \mathrm{~kg}$ for maize and $30 \mathrm{~kg}$ for beans) and Bwito (median $60 \mathrm{~kg}$ for maize and $50 \mathrm{~kg}$ for beans) chiefdoms (Table 3). The proportions of total quantity stored over total quantity produced for beans and maize were, respectively, $62 \%$ and $45 \%$ for Baswagha, $70 \%$ and $100 \%$ for Bwisha, and $41 \%$ and $40 \%$ for Bwito. Part of the grain produced was sold at harvest to meet the immediate cash needs of the HHs and the rest was stored for home consumption and or later sale. The proportions of total quantity consumed over total quantity stored for bean and maize were, respectively, $100 \%$ and $97.5 \%$ for Baswagha, $83.3 \%$ and $60 \%$ for Bwisha, and $80 \%$ and $83.3 \%$ for Bwito. Farmers in these chiefdoms stored grain primarily for $\mathrm{HH}$ consumption. 
Table 3. Storage practices and challenges faced by farmers in Baswagha, Bwisha, and Bwito chiefdoms of the North Kivu province, D. R. Congo.

\begin{tabular}{|c|c|c|c|c|c|}
\hline \multirow{2}{*}{ Variable } & \multirow{2}{*}{ Category } & Baswagha & Bwisha & Bwito & Total \\
\hline & & \multicolumn{4}{|c|}{ Percentage (Standard Error) } \\
\hline \multirow{3}{*}{ Main crop stored (\%) } & & $\mathrm{n}=220$ & $\mathrm{n}=177$ & $\mathrm{n}=172$ & $\mathrm{n}=569$ \\
\hline & Beans & $84.1(2.5)$ & $69.5(3.4)$ & $89.5(2.3)$ & $80.1(1.7)$ \\
\hline & Maize & $15.9(2.5)$ & $30.5(3.4)$ & $10.5(2.3)$ & $19.9(1.7)$ \\
\hline \multirow{6}{*}{ Reason to not store $(\%)$} & & $\mathrm{n}=51$ & $\mathrm{n}=59$ & $\mathrm{n}=11$ & $\mathrm{n}=121$ \\
\hline & Good price at harvest & $5.9(3.3)$ & $5.1(2.8)$ & $0.0(0.00)$ & $5.2(2.07)$ \\
\hline & Insects & $27.5(6.2)$ & $15.3(4.7)$ & $45.5(14.8)$ & $22.6(3.8)$ \\
\hline & Need cash & $0.0(0.0)$ & $47.5(6.5)$ & $9.1(8.5)$ & $22.7(3.6)$ \\
\hline & Not enough production & $62.7(6.7)$ & $32.2(6.0)$ & $45.5(14.8)$ & $47.6(4.5)$ \\
\hline & Others & $3.9(2.7)$ & $0.0(0.0)$ & $0.0(0.0)$ & $1.9(1.32$ \\
\hline \multirow{5}{*}{$\begin{array}{l}\text { Main storage } \\
\text { protection method (\%) }\end{array}$} & & $\mathrm{n}=271$ & $\mathrm{n}=236$ & $\mathrm{n}=183$ & $\mathrm{n}=690$ \\
\hline & Do nothing & $82.3(2.3)$ & $52.5(3.2)$ & $44.3(3.6)$ & $66.0(1.7)$ \\
\hline & Botanicals & $6.3(1.5)$ & $21.6(2.7)$ & $47.5(3.6)$ & $17.8(1.3)$ \\
\hline & Pesticides & $9.2(1.8)$ & $24.6(2.8)$ & $6.0(1.7)$ & $14.3(1.3)$ \\
\hline & Hermetic & $2.2(1.0)$ & $1.3(0.7)$ & $2.2(1.1)$ & $1.9(0.5)$ \\
\hline \multirow{8}{*}{$\begin{array}{l}\text { Reason to not use } \\
\text { pesticides }(\%)\end{array}$} & & $\mathrm{n}=252$ & $\mathrm{n}=163$ & $\mathrm{n}=126$ & $\mathrm{n}=541$ \\
\hline & Not available & $19(2.5)$ & $33.7(3.7)$ & $39.7(4.3)$ & $26.1(1.9)$ \\
\hline & No information & $29(2.8)$ & $26.4(3.4)$ & $11.9(2.8)$ & $26.0(2.0)$ \\
\hline & Toxic & $18.7(2.4)$ & $20.2(3.1)$ & $5.6(2.0)$ & $17.5(1.7)$ \\
\hline & Not effective & $12.3(2.1)$ & $3.1(1.3)$ & $32.5(4.1)$ & $12.0(1.4)$ \\
\hline & Expensive & $10.7(1.9)$ & $6.1(1.9)$ & $6.3(2.1)$ & $8.8(1.3)$ \\
\hline & No insect problems & $7.1(1.6)$ & $6.7(2.0)$ & $4.0(1.7)$ & $6.6(1.1)$ \\
\hline & Not enough production & $3.2(1.1)$ & $3.7(1.5)$ & $0.0(0.0)$ & $2.9(0.8)$ \\
\hline
\end{tabular}

Most farmers stored their grain inside their house $(91.1 \%$ in Baswagha, $92.4 \%$ in Bwisha, and $93.4 \%$ in Bwito). Most farmers ( $>95 \%$ ) in the three chiefdoms stored maize or beans for less than six months. About two thirds $(66.0 \%)$ of farmers did not protect their grains during storage; with the highest number in Baswagha (Table 3). Insects were the major challenge during maize and beans storage (Table 4). The importance of the other sources of losses varied by crop and chiefdom. Farmers had rodent attacks on stored maize ( $42.9 \%$ of respondents) than beans ( $18.6 \%$ of respondents). The use of botanicals (plant parts and extracts) was the highest among farmers in Bwito (Table 3). Across chiefdoms, a limited number of farmers (14.3\%) used insecticides to protect their grain during storage. Insecticides were mostly applied on beans by farmers in Bwisha (25.4\%) and Bwito (30.6\%) (Table 4). About $52 \%$ of farmers noted that the limited use of insecticides as grain protectants was due to unavailability and lack of information (Table 3).

\subsection{Decision to Store and to Protect Grain during Storage}

The model used to evaluate factors that influence the decision to store grain was well fitted [LR test was significant $\left(X^{2}=17.96 ; d f=3 ; p=0.0004 / \mathrm{LR}=-311.38 ; d f=4\right)$ ]. Farmers' decisions to store grain were influenced by the crop they grew (beans or maize). Farmers who had contact with extension agents were more likely to store grain (ORs $=1.99$, $p=0.0008)$. The model to identify factors that influence the decision to protect grain during storage was well fitted for beans $(p=0.0000)$ and maize $(p=0.0232)$ (Table 5). Farmers in Bwisha and Bwito were more likely to protect their beans and maize (using botanicals, pesticides, or airtight containers) than farmers in Baswagha (Table 5). Furthermore, farmers who had contact with extension agents, and farmers who stored beans or maize for more than three months, were more likely to protect their crop (Table 5). 
Table 4. Maize and beans storage duration and sources of losses on smallholder farms in Baswagha, Bwisha, and Bwito chiefdoms of the North Kivu province, D. R. Congo.

\begin{tabular}{|c|c|c|c|c|c|c|c|c|}
\hline \multirow[b]{2}{*}{ Variables } & \multicolumn{4}{|c|}{ Beans [\% Respondents, (Standard Error)] } & \multicolumn{4}{|c|}{ Maize [\% Respondents, (Standard Error)] } \\
\hline & Baswagha & Bwisha & Bwito & Total & Baswagha & Bwisha & Bwito & Total \\
\hline Storage duration & $\mathrm{n}=185$ & $\mathrm{n}=123$ & $\mathrm{n}=154$ & $\mathrm{n}=462$ & $\mathrm{n}=35$ & $\mathrm{n}=54$ & $\mathrm{n}=18$ & $\mathrm{n}=107$ \\
\hline$<3$ months & $48.6(3.7)$ & $49.6(4.4)$ & $48.1(4.0)$ & $48.8(2.4)$ & $71.4(7.6)$ & $68.5(6.3)$ & $61.1(11.3)$ & $69(4.4)$ \\
\hline $3-6$ months & $45.9(3.6)$ & $46.3(4.4)$ & $51.3(4.0)$ & $47.1(2.4)$ & $28.6(7.6)$ & $24.1(5.8)$ & $38.9(11.3)$ & $27.2(4.5)$ \\
\hline 6-9 months & $5.4(1.6)$ & $4.1(1.8)$ & $0.0(0.0)$ & $4.0(1.0)$ & $0.0(0.0)$ & $7.4(3.5)$ & $0.0(0.0)$ & $3.8(1.8)$ \\
\hline$>9$ months & $0.0(0.0)$ & $0.0(0.0)$ & $0.6(0.6)$ & $0.1(0.1)$ & $0.0(0.0)$ & $0.0(0.0)$ & $0.0(0.0)$ & $0.0(0.0)$ \\
\hline Source of losses ${ }^{\text {a }}$ & $\mathrm{n}=185$ & $\mathrm{n}=123$ & $\mathrm{n}=154$ & $\mathrm{n}=462$ & $\mathrm{n}=35$ & $\mathrm{n}=54$ & $\mathrm{n}=18$ & $\mathrm{n}=107$ \\
\hline Insects & $89.2(2.3)$ & $97.6(1.4)$ & $95.5(1.7)$ & $92.8(1.3)$ & $68.6(7.8)$ & $90.7(3.9)$ & $83.3(8.6)$ & $81.3(3.9)$ \\
\hline Rodents & $25.4(3.2)$ & $11.4(2.9)$ & $11(2.5)$ & $18.6(1.9)$ & $51.4(8.4)$ & $37(6.5)$ & $38.9(11.3)$ & $42.9(4.9)$ \\
\hline Molds & $34.1(3.5)$ & $4.9(1.9)$ & $7.8(2.1)$ & $20.6(2.0)$ & $14.3(5.9)$ & $0.0(0.0)$ & $22.2(9.6)$ & $7.7(2.6)$ \\
\hline Theft & $4.3(1.5)$ & $2.4(1.4)$ & $1.9(1.1)$ & $3.3(0.9)$ & $5.7(3.9)$ & $1.9(1.8)$ & $0.0(0.0)$ & $3.2(1.8)$ \\
\hline \multirow{2}{*}{ Chemicals use ${ }^{b}$} & $\mathrm{n}=271$ & $n=236$ & $\mathrm{n}=183$ & $\mathrm{n}=690$ & $\mathrm{n}=271$ & $\mathrm{n}=236$ & $\mathrm{n}=183$ & $n=690$ \\
\hline & $6.6(1.5)$ & $25.4(2.8)$ & $30.6(3.4)$ & $16.9(1.4)$ & $0.4(0.4)$ & $14(2.2)$ & $2.7(1.2)$ & $5.6(0.8)$ \\
\hline
\end{tabular}

${ }^{a}$ Multiple choice questions; respondent may have picked more than one response. ${ }^{b}$ Respondents who answered Yes for using chemicals to control pests during storage.

Table 5. Factors influencing farmers' decision to protect grain during storage in Baswagha, Bwisha, and Bwito chiefdoms of the North Kivu province, D. R. Congo.

\begin{tabular}{|c|c|c|c|c|c|c|}
\hline \multirow{2}{*}{ Variable } & \multicolumn{3}{|c|}{ Beans $^{a}$} & \multicolumn{3}{|c|}{ Maize $^{b}$} \\
\hline & $\mathrm{OR}^{\mathrm{c}}$ & $95 \% \mathrm{CI}^{\mathrm{d}}$ & $p$ Value & OR & $95 \% \mathrm{CI}$ & $p$ Value \\
\hline \multicolumn{7}{|l|}{ Chiefdom } \\
\hline Baswagha & 1.0 & (referent) & & 1.0 & (referent) & \\
\hline Bwisha & 5.4 & [2.9-10.3] & 0.000 & 13.4 & [2.3-107.1] & 0.007 \\
\hline Bwito & 5.1 & {$[3.1-8.6]$} & 0.000 & 9.6 & {$[1.3-88.3]$} & 0.031 \\
\hline Household size & 0.9 & {$[0.9-1.0]$} & 0.066 & 0.8 & {$[0.6-1.0]$} & 0.052 \\
\hline \multicolumn{7}{|c|}{ Contact with extension services? } \\
\hline No & 1.0 & (referent) & & 1.0 & (referent) & \\
\hline Yes & 2.0 & {$[1.3-3.1]$} & 0.002 & 1.1 & {$[0.4-3.2]$} & 0.913 \\
\hline Quantity produced (ln) & 1.1 & [0.8-1.5] & 0.630 & 0.6 & [0.2-1.2] & 0.170 \\
\hline Quantity stored (ln) & 1.1 & {$[0.8-1.6]$} & 0.486 & 1.2 & {$[0.6-2.7]$} & 0.565 \\
\hline \multicolumn{7}{|c|}{ Problems with insects during storage } \\
\hline No & 1.0 & (referent) & & 1.0 & (referent) & \\
\hline Yes & 1.5 & {$[0.6-4.1]$} & 0.382 & 0.4 & {$[0.1-2.3]$} & 0.309 \\
\hline \multicolumn{7}{|l|}{ Storage duration } \\
\hline Less than 3 months & 1.0 & (referent) & & 1.0 & (referent) & \\
\hline More than 3 months & 1.6 & {$[1.0-2.5]$} & 0.036 & 5.0 & [1.3-25.3] & 0.032 \\
\hline
\end{tabular}

a Bean model Likelihood ration (LR) test: Chi-square $\left(\mathrm{X}^{2}\right)=91.81$; degrees of freedom $(\mathrm{df})=8 ; p=0.0000 / \mathrm{LR}=-270.5839(\mathrm{df}=9)$.

${ }^{\mathrm{b}}$ Maize model LR test: $\mathrm{X}^{2}=17.74 ; \mathrm{df}=8 ; p=0.0232 / \mathrm{LR}=-49.30(\mathrm{df}=9) .{ }^{\mathrm{c}} \mathrm{OR}=$ odds ratio. ${ }^{\mathrm{d}} \mathrm{CI}=$ confidence interval.

\subsection{Decision to Store Bean and Maize Seed}

Farmers stored seed to plant in the following season, but quantities differed by crop. Most farmers in the three chiefdoms stored more bean than maize seed (Figure 2). All farmers stored bean seed, but maize seed was most stored in Bwisha by $87.5 \%$ of respondents (Table 6). The logistic regression showed that farmers in Bwisha and Bwito were more likely to store bean and maize seed than farmers in Baswagha (Table 6). In addition, farmers in Bwito stored significantly higher quantities of seed (median of $30 \mathrm{~kg}$ for beans and $15 \mathrm{~kg}$ for maize) compared to farmers in Bwisha (median of $22 \mathrm{~kg}$ for beans and $8 \mathrm{~kg}$ for maize) and Baswagha (median of $15 \mathrm{~kg}$ for beans and $5 \mathrm{~kg}$ for maize) (Figure 2). Declared seed storage losses by farmers were higher on maize than on beans. Maize and bean seed 
weight losses were $50 \%$ and $31.5 \%$ in Baswagha, $35 \%$ and $15 \%$ in Bwisha, and $50 \%$ and $30 \%$ in Bwito, respectively.

Table 6. Factors influencing farmers' decision to store bean and maize seed in Baswagha, Bwisha, and Bwito chiefdoms of the North Kivu province, D. R. Congo.

\begin{tabular}{|c|c|c|c|c|}
\hline Farmers Who Kept Bean Seed & \% Mean (Standard Error) & $\mathrm{OR}^{\mathrm{a}}$ & $95 \% \mathrm{CI}^{\mathrm{b}}$ & $p$ \\
\hline Baswagha $\left(\mathrm{n}_{\text {bean }}=180 ; \mathrm{n}_{\text {maize }}=44\right)$ & $86.5(2.35)$ & 1.0 & (referent) & \\
\hline Bwisha $\left(\mathrm{n}_{\text {bean }}=159 ; \mathrm{n}_{\text {maize }}=147\right)$ & $94.6(1.72)$ & 2.8 & [1.3-6.3] & 0.011 \\
\hline Bwito $\left(\mathrm{n}_{\text {bean }}=141 ; \mathrm{n}_{\text {maize }}=57\right)$ & $93.4(1.99)$ & 2.2 & [1.1-4.9] & 0.041 \\
\hline$L R^{\mathrm{c}}$ test & \multicolumn{4}{|c|}{$X^{2}=8.7 ; d f=2 ; p=0.0127 L R=-154.1(d f=3)$} \\
\hline Farmers who kept Maize seed & \% Mean (Standard Error) & OR & $95 \%$ CI & \multirow[t]{2}{*}{$p$} \\
\hline Baswagha $\left(\mathrm{n}_{\text {bean }}=180 ; \mathrm{n}_{\text {maize }}=44\right)$ & $21.2(2.82)$ & 1.00 & (referent) & \\
\hline Bwisha $\left(\mathrm{n}_{\text {bean }}=159 ; \mathrm{n}_{\text {maize }}=147\right)$ & $87.5(2.53)$ & 26.0 & [15.1-47.0] & 0.000 \\
\hline Bwito $\left(\mathrm{n}_{\text {bean }}=141 ; \mathrm{n}_{\text {maize }}=57\right)$ & $37.7(3.88)$ & 2.3 & {$[1.4-3.6]$} & 0.000 \\
\hline LR test & \multicolumn{4}{|c|}{$X^{2}=187.3 ; d f=2 ; p=0.0000 L R=-270.7(d f=3)$} \\
\hline
\end{tabular}

${ }^{\mathrm{a}} \mathrm{OR}=$ odds ratio. ${ }^{\mathrm{b}} \mathrm{CI}=$ confidence interval. ${ }^{\mathrm{c}} \mathrm{LR}=$ Likelihood Ratio test; $X^{2}=$ Chi-square value; $d f=$ degrees of freedom; $p=$ probability value.

\subsection{Estimates of Return on Investment (ROI) Using Hermetic Bags}

The use of airtight containers (hermetic methods), such as the PICS bags, is being promoted in North Kivu by development partners including government and NGOs. We estimated the ROI to assess the profitability of storing grain using PICS bags in the three chiefdoms. The ROI after storing grain for six months in PICS bags varied by chiefdom and crop (Table 7). Chiefdoms with the highest ROI (above 50\%) were Bwisha for beans $(54 \%)$ and Baswagha for both maize $(63 \%)$ and beans (51\%) (Table 7).

Table 7. Estimated return on investment (ROI) when farmers store maize or beans for six months using a 100-kg PICS bag in Baswagha, Bwisha, and Bwito chiefdoms of the North Kivu province, D. R. Congo.

\begin{tabular}{|c|c|c|c|c|c|c|c|c|}
\hline \multirow[b]{2}{*}{ Chiefdom } & \multirow{2}{*}{ Crop } & \multicolumn{2}{|c|}{ Price (FC/100 kg) } & \multicolumn{4}{|c|}{ Amount (FC) } & \multirow{2}{*}{$\begin{array}{c}\% \\
\text { ROI }^{c}\end{array}$} \\
\hline & & Harvest & Lean Season & Gross Margin & Price HS Bag ${ }^{a}$ & OCC $^{b}$ & Net Gain & \\
\hline \multirow[t]{2}{*}{ Baswagha } & $\begin{array}{l}\text { Maize } \\
(\mathrm{n}=35)\end{array}$ & 21,286 & 41,457 & 20,171 & 3000 & 2186 & 14,986 & 63 \\
\hline & $\begin{array}{c}\text { Beans } \\
(\mathrm{n}=185)\end{array}$ & 39,741 & 68,081 & 28,341 & 3000 & 3847 & 21,494 & 51 \\
\hline \multirow[t]{2}{*}{ Bwisha } & $\begin{array}{l}\text { Maize } \\
(\mathrm{n}=54)\end{array}$ & 18,185 & 30,333 & 12,148 & 3000 & 1907 & 7241 & 37 \\
\hline & $\begin{array}{c}\text { Beans } \\
(\mathrm{n}=123)\end{array}$ & 37,398 & 64,187 & 26,789 & 3000 & 3636 & 20,153 & 54 \\
\hline \multirow[t]{2}{*}{ Bwito } & $\begin{array}{l}\text { Maize } \\
(\mathrm{n}=18)\end{array}$ & 16,492 & 24,686 & 8194 & 3000 & 1754 & 3440 & 18 \\
\hline & $\begin{array}{c}\text { Beans } \\
(\mathrm{n}=154)\end{array}$ & 35,574 & 54,839 & 19,265 & 3000 & 3472 & 12,794 & 37 \\
\hline
\end{tabular}

a Price of a $100 \mathrm{~kg}$ hermetic storage (HS) bag in North Kivu (Congolese Francs, FC); as of August 31, 2016 (US $\$ 1=1000$ FC). ${ }^{\mathrm{b}}$ OCC: Opportunity cost of capital is estimated at $9 \%$ for 6 months (based on commercial bank interest rates on loans in 2016). ${ }^{c}$ ROI: Return on investments estimates are conservative because the cost is for one-season use (some HST bags can be used for 2 or 3 years).

\section{Discussion}

\subsection{Cereal and Legume Crops Produced and Production}

The results of this study confirm that beans and maize were the commonly cultivated legume and cereal crops, respectively, across the three chiefdoms [26]. Beans were the major grain cultivated followed by maize; a trend that has been maintained in North Kivu since 2012 [15]. We also found that in Bwisha and Bwito farmers were growing additional crops including soybean, sorghum, and peanut. Soybean was produced as a limited alternative to beans and was mostly sold to buyers in local and export markets [27]. 
Overall, crop production was low and may have been severely affected by conflicts. For instance, prolonged conflict and insecurity in the Kivus affected the overall bean production in the DRC, dropping from 180,000 tons in 1994 to 107,000 tons in 2002 (USAID, 2015). Average production of $55 \mathrm{~kg}$ of beans per farmer registered in North and South Kivu in 2009 was reflective of the insecurity situation in eastern DRC [28]. This bean production level is very similar to that of farmers in Baswagha but lower than that of farmers in Bwisha and Bwito.

Crop production in North Kivu is generally low compared to DRC's neighboring countries. The average bean production per farmer in all three chiefdoms was lower than that of a farmer in Burundi $(254 \mathrm{~kg})$ in 2012 [29]. Low bean production in North Kivu, exacerbated by conflicts, was mainly due to the use of poor quality seed and limited application of fertilizer [9]. The increase in bean production in Bwisha and Bwito from 2009 to 2016 may have been explained by the interventions of NGOs in the sector that provided free inputs and technical assistance $[9,30]$. Maize production in North Kivu, especially in Rutshuru, substantially decreased by about half during the insecurity periods; going from $300 \mathrm{~kg}$ to about 100 to $200 \mathrm{~kg}$ per smallholder farmer per season [31]. Maize production under insecurity situations is similar to that observed in this study.

\subsection{Postharvest Handling and Storage}

Most important sources of loss during field drying varied among the three chiefdoms and included theft, rotting, animal damage, and insect infestation. High rainfall combined with low temperatures in the highlands provided the optimum environment for mold growth. Mold development is common, especially when there is rain during field drying [25]. Just as for farmers in many other developing countries, insects constituted one of the major challenges during field drying [32]. We also observed that crop theft was one of the more prevalent challenges during field drying in Bwisha and Bwito. Crop theft incidences were pronounced in areas experiencing armed conflicts such as Rutshuru territory [26]. Crop damage by livestock during field drying (e.g., maize and sorghum) was common and the major source of friction and violence between herders and crop producers in North Kivu [26,33,34].

Crop theft and damage by livestock often forced farmers to harvest their crops before they fully matured or field drying is completed, leading to further losses. Drying is often continued at the homestead, once grain is harvested. Crops are sun-dried on tarpaulins, mats, thin layers of plastic, or on the ground. Issues of mold and pests are interconnected as fungal contamination easily develop on grain damaged by insects, and farmers are often unaware of good postharvest practices to mitigate them [35]. A recent study conducted in South Kivu revealed that only $12 \%$ of farmers knew that proper drying of maize was effective in reducing fungal contamination [36]. Disseminating efficient technologies, such as the EasyDryM500, a portable dryer developed in Kenya, would help reduce losses during drying [37]. This mobile dryer speeds up drying by reducing maize moisture content from $20 \%$ to $13 \%$ in about three hours. Shortening the drying time using the EasyDryM500 would minimize field drying and hence reduce losses due to mold, theft, insects, and livestock.

Grain storage was important and played a significant role in all chiefdoms. Most farmers (i.e., Rutshuru) stored a significant proportion of their production (30 to $60 \%$ for maize) to ensure that they were food-secure between cropping seasons. These results are corroborated by other studies that show about 60 to $70 \%$ of grain produced in North Kivu was used for home consumption $[9,11,31,38]$. The fact that $91 \%$ and $21 \%$ of farmers stored beans and maize, respectively, shows the importance of beans as a food security and cash crop across the three chiefdoms. This may explain why interventions by development partners heavily focused on beans.

Farmers faced numerous challenges during storage, mostly due to pests. A study conducted in eastern DRC found that $68 \%$ of farmers were affected by postharvest losses [15]. This study, like several others, confirms that the biggest storage issues on smallholder farms 
were associated with insects and rodents [9,39]. Rodents appeared to be more prevalent during maize than beans storage, and more pronounced in Baswagha than any other chiefdom. Rodents have been reported as a serious pest of stored grain in Kisangani, Tshopo province, DRC [40]. Molds during storage in Baswagha were the result of storing grain that is not properly dried. There was minimal use of improved storage technologies in eastern DRC to reduce losses due to insect pests [15]. Scaling-up the use of hermetic bags that have been promoted in sub-Saharan Africa to more than seven million smallholder farmers would help reduce storage losses due to insects in the North Kivu province [41].

Safe seed storage is key to farmers' food security as the saved seed is the second largest source of planting material for the next growing season in the DRC [42]. Farmers in Baswagha were less likely to store seed than those in Bwisha and Bwito. When farmers in Baswagha stored seed, the quantity was small, and losses were higher. Seed storage losses were common on smallholder farms, and ranged from $25-95 \%$ in the Kasai province, DRC [13]. Farmers in Baswagha relied more on local markets to purchase seed like those in Katanga province [42]. Improved seed storage technologies would help to maintain seed quality and minimize losses due to insects and high humidity [43,44]. Promoting hermetic storage methods, including use of jerrycans, bottles, and hermetic bags, would help farmers preserve seed quality during storage [45].

\subsection{Farmers' Decision to Store and to Protect Grain and Seed}

Grain protection during storage varied markedly among the three chiefdoms. In Baswagha, less than $20 \%$ of farmers took any action to protect their stored grains, while, in Bwito and Bwisha, the likelihood to do so increased significantly (for about 50\%), although the protection strategies were different. Most farmers in Bwito and about half of those in Bwisha used botanicals to protect stored grains; as some of these products are locally available and have shown to be effective $[1,17]$. The use of inputs (i.e., pesticides and fertilizers) in the DRC is low due to several challenges including unavailability, ineffectiveness, cost, lack of information, and limited knowledge on how to use them [38,40,46]. Extension services are largely defunct except when supplied by development partners including NGOs, donors, and projects [9]. Several projects introduced hermetic bags (e.g., PICS bags) in DRC to address insect pests, but the adoption has been limited [15]. Contact with development partners increased the likelihood of farmers to protect their grain during storage. The fact that farmers who stored for longer were likely to protect their grains suggest that improved storage technologies, such as hermetic bags (e.g., PICS bags, SuperGrainbags ${ }^{\mathrm{TM}}$, etc.), would be attractive to these smallholder farmers [25,47]. The role of beans and maize as food security and cash crops may explain why farmers in Bwisha and Bwito heavily saved seed for planting the following season. Lower losses during seed storage in Bwisha might be explained by farmers taking protection measures.

\subsection{Estimates of Return on Investment (ROI) Using Hermetic Bags}

Conflicts and market channel systems for grains affected farmers and crop production [11,31]. In most developing countries, farmers sell their crops at harvest to meet household needs [48]. In the lean season, grain prices increase, making household food requirements hard to meet. Therefore, improving crop storage capabilities can effectively strengthen food security and increase access to more lucrative markets [15,29]. Using improved storage (e.g., hermetic bags) will likely provide an opportunity for economic return regardless of the grain stored and the chiefdom. Maize and bean ROIs observed in the three chiefdoms are similar to those obtained in eastern Kenya and in Lubumbashi in the DRC [24,49]. Awareness building and trainings are needed to increase the use of improved storage technologies among farmers and other actors along the maize and bean value chains. 


\section{Conclusions}

Most studies conducted in the North Kivu province have focused on production and market access with limited emphasis on postharvest. This study is one of the few that provides insights into postharvest management practices of grain crops and seed, and highlights farmers' actual needs for future interventions to reduce losses. Maize and beans are the major cereal and legume crops produced by farmers in Baswagha, Bwisha, and Bwito. Maize and beans have several drying and storage challenges including insects, rodents, animals, and theft. Overall, rotting was the major challenge during field drying, particularly severe in Baswagha. However, theft was the most important challenge during field drying in Bwisha and Bwito. Storage was severely hampered by low crop production and insects. For most farmers who stored, over half of them did not protect their stored stocks, hence increasing grains and seeds susceptibility to pest attacks. There is an opportunity to introduce or scale-up improved postharvest technologies (e.g., EasyDry500 and hermetic bags) in the North Kivu province. Scaling up these technologies would help to mitigate grain losses due to mold, theft, and insects during drying and storage. This would provide smallholder farmers the opportunity to secure quality grain for home consumption and sale, and seed for planting.

Author Contributions: Conceptualization, D.B., A.L., I.B.B., L.S., J.P.C.N.; methodology, D.B., A.L., I.B.B., L.S.; software, D.M., J.R.D.-V., D.B.; validation, D.M., A.L., J.R.D.-V., D.B, I.B.B.; formal Analysis, D.M., J.R.D.-V., D.B.; investigation, D.M., A.L., J.P.C.N.; resources, D.M., A.L., J.P.C.N., D.B., L.S.; data Curation, D.M., J.R.D.-V., D.B.; writing-Original Draft Preparation, D.B., J.R.D.-V.; writing-Review \& Editing, J.R.D.-V., I.B.B., L.S., D.B., J.P.C.N., D.M., A.L.; visualization, D.M., J.R.D.-V., A.L., D.B., I.B.B.; supervision, D.B., D.M., A.L., J.P.C.N.; project Administration, D.B., J.P.C.N.; funding Acquisition, D.B., L.S. All authors have read and agreed to the published version of the manuscript.

Funding: This survey was part of a project "Enhancing seed and grain storage capacity for smallholder farmers in Eastern Democratic Republic of Congo (North Kivu)" funded by Catholic Relief Services to Purdue University (Grant number 209094). AL, J.P.C.N., D.M., and D.B. received salary from the funder institution. The funder had no role in the study design, data collection and analysis, decision to publish, or preparation of the manuscript.

Institutional Review Board Statement: The study was conducted according to the guidelines of the Declaration of Helsinki, and approved by the Institutional Review Board (or Ethics Commit-tee) of Purdue University (protocol code 1405014885).

Informed Consent Statement: Informed consent was obtained from all subjects involved in the study.

Data Availability Statement: Raw data is not publicly available, though the data may be made available on request from the corresponding author.

Acknowledgments: We thank the management of the Catholic Relief Services (CRS) office in Goma for their support in securing the grant and facilitating the implementation of the survey. We also thank the enumerators for their time, commitment, and dedication in collecting the data under conflict situations. Finally, we thank all the local leaders in the three chiefdoms for facilitating access to their communities and farmers for agreeing to participate in this survey.

Conflicts of Interest: Dieudonne Baributsa is co-founder of PICS Global, a private company that is commercializing the Purdue Improved Crop Storage (PICS) bags around the world; hence declare a conflict of interest. This study was conducted to assess postharvest challenges among farmers in North Kivu, the Democratic Republic of Congo; for the purpose of exploring the potential dissemination of handling and storage technologies including PICS bags. This competing interest does not alter our adherence to Sustainability policies on sharing data and materials. Jean Paul Nshombo (former employee of Catholic Relief Services-CRS, the funder) is currently employed by Land O'Lakes, Inc. a private company which was not involved in this study; hence has no conflict to declare. Jean Paul Nshombo worked for CRS during the implementation of this study and left for Land O'Lakes, Inc. in mid-2020. The other co-authors do not have any conflict of interest. 


\section{References}

1. Smith, E.D.; Bonhomme, S.; Sinclair, F. Guide Technique D'agroforesterie Pour la Selection et la Gestion des Arbres au Nord Kivu; The World Agroforestry Centre: Nairobi, Kenya, 2015.

2. Guluma, Y. Household Economy Analysis of the Rural Population of South-Western Bwito. 2003. Available online: https: / / reliefweb.int/sites/reliefweb.int/files/resources/E6916D970D51870A49256CDB002B6828-scf-drc-31jan1.pdf (accessed on 12 November 2020).

3. Reyntjens, F. Briefing: The secong Congo war: More than a remake. Afr. Aff. 1999, 98, 241-250. [CrossRef]

4. Stearns, J. The Background to Conflict in North Kivu Province of Eastern Congo; Rift Valley Institute: Nairobi, Kenya, 2012.

5. FAO/WFP. Monitoring Food Security in Countries with Conflict Situations; FAO/WFP: Rome, Italy, 2017.

6. Muraya, B.J.; Ahere, J. Perpetuation of Instability in the Democratic Republic of the Congo: When the Kivus Sneeze, Kinshasa Catches a Cold; ACCORD: Umhlanga Rocks, South Africa, 2014.

7. MINPLAN. Localisation des Objectifs de Développement Durable dans le Nord-Kivu. 2017. Available online: https://www. local2030.org/library/406/Locating-the-SDGs-in-North-Kivu-Provincial-Report.pdf (accessed on 12 November 2020).

8. CAID. Securité Alimentaire, Niveau de Production Agricole et Animale, Evaluation de la Campagne Gricole 2017-2018 et Bilan Alimentaire du Pays; Ministère de l'Agriculture: Kinshasa, Democratic Republic of the Congo, 2018.

9. USAID. Assessment of the DRC's Agriculture Market Systems: Value Chain in the North \& South Kivu and Katanga Provinces; Leveraging Economic Opportunties (LEO) Report \#16; USAID: Washington, DC, USA, 2015.

10. Nyamwaro, S.O.; Kalibwani, R.; Wimba, B.; Muke, A.; Tenywa, M.M.; Mugabo, J.; Buruchara, R.; Oluwole, F.O. Innovation Opportunities in Bean Production in the DR Congo; FARA Research Reports: Washington, DC, USA, 2018; Volume 2, p. 16.

11. Njingulula, P.M.; Kaganzi, E. Overcoming Market Constraint for Pro-poor Agricultural Growth in the Eastern DR Congo, South Kivu. In Innovations as Key to the Green Revolution in Africa; Bationo, A., Waswa, B., Okeyo, J.M., Maina, F., Kihara, J.M., Eds.; Springer: Dordrecht, The Netherlands, 2011; pp. 1083-1089. ISBN 978-90-481-2541-8.

12. CIAT; UEA; CRS; Caritas. Seed System Security Assessment, Northern Katanga (Kalemie and Nyunzu Territories), Democratic Republic of Congo; Catholic Relief Services and International Center for Tropical Agriculture: Kinshasa, Democratic Republic of the Congo, 2012.

13. Budikadidi/Catholic Relief Services. Seed System Security Assessment, Kasai Oriental, Democratic Republic of Congo; Catholic Relief Services and International Center for Tropical Agriculture: Kinshasa, Zaire, 2017.

14. Keita, M.L. Evaluation of the Baseline Situation in the RISE Intervention Area; P.L. 480 Title II Multi-Year Assistance Program, FP-A-11-00008; Final draft; 2012; Available online: https:/ /www.thegef.org/sites/default/files/documents/10314_Project_ Document_1.pdf (accessed on 12 November 2020).

15. Murphy, E.; Glaeser, L.; Maalouf-Manasseh, Z.; Collison, D.K.; Sethuraman, K. USAID Office of Food for Peace Food Security Desk Review for Katanga, North Kivu, and South Kivu, Democratic Republic of Congo. 2015. Available online: https://www. fantaproject.org/sites/default/files/resources/FFP-Kivu-Katanga-Desk-Review-Nov2015.pdf (accessed on 12 November 2020).

16. Kaloma, A.; Kitambala, K.; Ndjango, N.; Sinzahera, U.; Paluku, T. Effet des poudres d'Eucalyptus citriodora, de Cupressus lucitanica et de Tagetas minitiflora dans la conservation du maïs (Zea mays) et du haricot (Phaseolus vulgaris) dans les conditions de Rethy, République Démocratiqu. Tropicultura 2008, 26, 24-27.

17. Semacumu, G.; Kulimushi, E.; Bahige, P. Etude de l'efficacité des poudres des quelques plantes locales dans la lutte post- récolte contre les insectes ravageurs des grains de maïs (Zea mays) en conservation à Goma. 2011. Available online: https://www.researchgate.net/publication/273400658_ETUDE_DE_L \T1 \textquoterightEFFICACITE_DES_POUDRES_ DES_QUELQUES_PLANTES_LOCALES_DANS_LA_LUTTE_POST-RECOLTE_CONTRE_LES_INSECTES_RAVAGEURS_ DES_GRAINS_DE_MAIS_ZEA_MAYS_EN_CONSERVATION_A_GOMA (accessed on 12 November 2020).

18. Appelhans, T.; Detsch, F.; Reudenbach, C.; Woellauer, S.; Forteva, S.; Nauss, T.; Pebesma, E.; Russell, K.; Sumner, M.; Darley, J.; et al. Mapview: Interactive Viewing of Spatial Data in R, R Package, version 2.9.0; Vienna, Austria, 2020; Available online: https:/ / cran.r-project.org/web/packages/mapview / mapview.pdf (accessed on 12 November 2020).

19. Dauenhauer, P.; Shields, M.; Sloughter, J.M.; Stewart, A.J.; Lacrampe, C.; Magness, E.; Ochavillo, J.; Limfueco, J.; Mendoza, A. Improving Shoestring Surveys for Off-grid Humanitarian Power Projects: Kilowatts for Humanity and KoboCollect. 2018. Available online: https:/ / ieeexplore.ieee.org/document/8601657 (accessed on 12 November 2020).

20. Lumley, T. Package "survey". R Package Version 2015, 3, 3-30.

21. Hale, A.Z. In Search of Peace: An Autopsy of the Political Dimensions of Violence in the Democratic Republic of Congo. Ph.D. Thesis, University of Florida, Gainesville, FL, USA, 2009.

22. OCHA. IDPs: Population and Location in North Kivu, South Kivu and Manemia; OCHA: Kinshasa, Democratic Republic of Congo, 2004.

23. De Mendiburu Delgado, F. Una Herramienta de Análisis Estadístico Para la Investigación Agrícola. Master's Thesis, Universidad Nacional de Ingeniería, Lima, Peru, 2009.

24. Baributsa, D.; Njoroge, A.W. The use and profitability of hermetic technologies for grain storage among smallholder farmers in eastern Kenya. J. Stored Prod. Res. 2020, 87, 101618. [CrossRef] [PubMed]

25. Díaz-Valderrama, J.R.; Njoroge, A.; Macedo-Valdivia, D.; Orihuela-Ordóñez, N.; Smith, B.W.; Casa-Coila, V.; Ramírez-Calderón, N.; Zanabria-Gálvez, J.; Woloshuk, C.; Baributsa, D. Postharvest practices, challenges and opportunities for grain producers in Arequipa, Peru. PLoS ONE 2020, 15, e.0240857. [CrossRef] [PubMed]

26. Kibriya, S.; Savio, G.; Price, E.; King, J. The Role of Conflict in Farmers' Crop Choices in North Kivu, Democratic Republic of the Congo. Int. Food Agribus. Manag. Rev. 2016, 19, 99-118. 
27. Rinck, D.; Ciza, A.M.; Simplex, M. Political Economy Analysis: Democratic Republic of Congo Coffee, Soybean, and Beams Value Chains. 2017. Available online: https://imlive.s3.amazonaws.com/Federal\%20Government/ID33853131689855556914326540608 3626794731/Attachment\%20J.6\%20-\%202017\%20Political\%20Economy\%20Analysis\%20(PEA).pdf (accessed on 12 November 2020).

28. Ross, K.; Dalton, T.; Featherstone, A. A Nonparametric Efficiency Analysis of Bean Producers from North and South Kivu. In Proceedings of the Southern Agricultural Economics Association Annual Meeting, Atlanta, Georgia, 31 January-3 February $2009 ;$ p. 20.

29. Niragira, S.; D’Haese, M.; D’Haese, L.; Ndimubandi, J.; Desiere, S.; Buysse, J. Food for survival: Diagnosing crop patterns to secure lower threshold food security levels in farm households of Burundi. Food Nutr. Bull. 2015, 36, 196-210. [CrossRef] [PubMed]

30. Njingulula, P.; Wimba, P.; Musakamba, M.; Masuki, K.F.; Katafiire, M.; Ugen, M.; Birachi, E. Strengthening local seed systems within the bean value chain: Experience of agricultural innovation platforms in the Democratic Republic of Congo. Afr. Crop. Sci. J. 2014, 22, 1003-1012.

31. Boulinaud, M.; Pin, N. Etudes des Systèmes de Marchés du Haricot et du Mais; Analyse et Cartographie du Marché en Situation D'urgence (EMMA): Goma, Democratic Republic of the Congo, 2013.

32. Njoroge, A.W.; Baoua, I.; Baributsa, D. Postharvest Management Practices of Grains in the Eastern Region of Kenya. J. Agric. Sci. 2019, 11, 33. [CrossRef] [PubMed]

33. Luneghe, M.K. Tension between Herders and Farmers High as Violent Disputes Increase in Rural DR Congo. Available online: https:/ /globalpressjournal.com/africa/democratic-republic-of-congo/tension-herders-farmers-high-violent-disputesincrease-rural-drc/ (accessed on 11 November 2020).

34. Barrera, A. The Congo trap: MONUSCO islands of stability in the sea of instability. Stability 2015, 4, 1-16. [CrossRef]

35. Wagacha, J.M.; Muthomi, J.W. Mycotoxin problem in Africa: Current status, implications to food safety and health and possible management strategies. Int. J. Food Microbiol. 2008, 124, 1-12. [CrossRef] [PubMed]

36. Udomkun, P.; Wossen, T.; Nabahungu, N.L.; Mutegi, C.; Vanlauwe, B.; Bandyopadhyay, R. Incidence and farmers' knowledge of aflatoxin contamination and control in Eastern Democratic Republic of Congo. Food Sci. Nutr. 2018, 6, 1607-1620. [CrossRef] [PubMed]

37. Walker, S.; Davies, B. Feasibility of Up-Scaling the EasyDry M500 Portable Maize Dryer to Kenya; USAID—Bill \& Melinda Gates Foundation: Washington, DC, USA. Available online: https: / www.acdivoca.org/2017/04/feasibility-of-up-scaling-the-easydrym500-portable-maize-dryer-to-kenya / (accessed on 29 November 2020).

38. Martini, M. République Démocratique du Congo: Analyse de la Sécurité Alimentaire et de la Vulnérable (CFSVA); Rome, Italy, 2005; Available online: https:/ / documents.wfp.org/stellent/groups/public/documents/ena/wfp085442.pdf (accessed on 12 November 2020).

39. Abdoulaye, T.; Ainembabazi, J.H.; Alexander, C.; Baributsa, D.; Kadjo, D.; Moussa, B.; Omotilewa, O.; Ricker-Gilbert, J.; Shiferaw, F. Postharvest Loss of Maize and Grain Legumes in Sub-Saharan Africa: Insights from Household Survey Data in Seven Countries. 2016. Available online: https:/ / www.extension.purdue.edu/extmedia/ec/ec-807-w.pdf (accessed on 12 November 2020).

40. Amundala, N.D.; Kennis, J.; Leirs, H.; Migimiru, D.A. Farmer survey in the hinterland of Kisangani (Democratic Republic of Congo) on rodent crop damage and rodent control techniques used. Mammalia 2008, 72, 192-197. [CrossRef]

41. Baributsa, D.; Ignacio, M.C. Developments in the use of hermetic bags for grain storage. In Advances in Postharvest Management of Cereals and Grains; Maier, D.E., Ed.; Burleigh Dodds Science Publishing: Cambridge, UK, 2020; ISBN 978-1-78676-352-5.

42. McGuire, S.; Sperling, L. Seed systems smallholder farmers use. Food Secur. 2016, 8, 179-195. [CrossRef]

43. Afzal, I.; Bakhtavar, M.A.; Ishfaq, M.; Sagheer, M.; Baributsa, D. Maintaining dryness during storage contributes to higher maize seed quality. J. Stored Prod. Res. 2017, 72, 49-53. [CrossRef]

44. De Vitis, M.; Hay, F.R.; Dickie, J.B.; Trivedi, C.; Choi, J.; Fiegener, R. Seed storage: Maintaining seed viability and vigor for restoration use. Restor. Ecol. 2020, 28. [CrossRef]

45. Baributsa, D.; Baoua, I.B. Hermetic Seed Storage in PICS Bags. Available online: https://picsnetwork.org//wp-content/uploads/ 2018/03/Seed-Storage-Poster-FINAL-reduced-size.pdf (accessed on 12 November 2020).

46. Balangaliza, F.B. Uptake of Technology and Competitiveness of Legume Production in Small Scale Farming in South Kivu, Democratic Republic of Congo. Master's Thesis, Agribusiness Management and Trade, School of Agriculture and Enterprise Development, Kenyatta University, Nairobi, Kenya, 2014.

47. Manandhar, A.; Milindi, P.; Shah, A. An Overview of the Post-Harvest Grain Storage Practices of Smallholder Farmers in Developing Countries. Agriculture 2018, 8, 57. [CrossRef]

48. Kadjo, D.; Ricker-Gilbert, J.; Abdoulaye, T.; Shively, G.; Baco, M.N. Storage losses, liquidity constraints, and maize storage decisions in Benin. Agric. Econ. 2018, 49, 435-454. [CrossRef]

49. FAO. Point Sur le Prix des Denrées Alimentaires en RDC; Coordination des Opérations Agricole d'Urgence et de Réhabilitation FAO en RDC: Kinshasa, Democratic Republic of Congo, 2009. 